\title{
A Population Overlooked: Building Caring Relationships Between Military Children and Teachers
}

\author{
Heather Rogers Haverback \\ Towson University \\ Towson, $M D$ \\ Kathryn E. Bojczyk \\ The Catholic University of America \\ Washington, DC
}

\section{Introduction}

Last year marked the 15th anniversary of the September 11, 2001 attack. This event impacted not only the United States of America, but also the world. In fact, millions of children across the globe became sons and daughters of military parents after this event. These children have a distinct family situation, which impacts their education, development, and entire life.

\section{Importance}

Before becoming a professor, I (Heather Haverback) was an elementary and middle public school teacher. One of my teaching assignments was in Virginia, where I was teaching fifth grade on September 11,2001. That day impacted our nation, but it had not occurred to me how the impact was different for my many students living in military households.

Former Second Lady Dr. Jill Biden began to shed light on the needs of these children. In fact, she has called upon teachers and teacher educators to meet the needs of military children 
within their classrooms across the world, while creating positive student-teacher relationships and nurturing atmospheres. She highlighted the necessity for teachers to recognize this special population of students. After listening to Dr. Biden speak on this topic, it occurred to me that the population of military children and their families seem to have been overlooked. In fact, I remembered my students being picked up one by one on 9/11. Many of these students were being picked up by parents in military uniforms. Upon reflection, these students were dealing with a different set of issues.

Despite teaching one mile away from a military base and five miles from the Pentagon, my training had never included how to teach military children and how to deal with the issues they may face, such as ambiguous loss. For example, many students had one or both parents who were enlisted and deployed to far-away countries. In fact, many military personnel are deployed, return home, and then are deployed again (Hosek \& MacDermid Wadsworth, 2013). Thus, creating a climate of disruption for the children of the deployed parent.

Moreover, during these times of deployment the children were unsure of when they would speak with their parent, whether or not their parent was safe, and if their parent would ever return. These concerns were always apparent within the classroom. At times, a student's concern would show quietly within a writing assignment or more overtly through a student's behavior. Either way, I often felt unprepared as a teacher to deal with these unique circumstances. Interestingly, over 1 million school-age children are impacted by military relocation and deployment (Department of Defense, 2012); however, teacher education is not offered to address the needs of these students.

Many military children live off base and attend public schools. The classroom challenges for these children are unique, and because they move frequently, they may struggle in building and 
maintaining friendships and may experience stress and anxiety as they are dealing with the loss of a parent through deployment or even death. In fact, military children have to contend with changing academic standards, social adjustments, and issues with parental absence.

\section{Link to Theory}

Today, military families are embedded into the community, yet are often stated to have their own culture, which includes children living with the deployment of a parent (Blaisure, Saathoff-Wells, Pereira, MacDermid Wadsworth, \& Dombro, 2102). Pauline Boss (2004a) argues that both individual and collective perceptions are needed to understand how some families are resilient in the face of possible loss, especially if the event is ambiguous. An "ambiguous" loss occurs when the person is physically absent but psychologically present. For example, if a parent is actively deployed, he or she may be physically absent from the child, but psychologically present in the sense that the child is worried about his or her safety and well-being, which may be unknown, hence the ambiguity. It is in this way that a deployment can negatively impact children and challenge teachers and counselors within the classroom (Abell, 2004; Guidry, Simpson, Test, \& Bloomfield, 2013). Thus, creating a stable home and school environment for children from military families is vital (Holmes, Rauch, \& Cozza, 2013).

Although most families are eventually able to manage the stress associated with the loss of a member, some losses are more difficult to manage because they are complicated by ambiguity (Boss, 2004a). Boss $(1988,1992,2002)$ explains that it is the family members' perceptions of the situation that prevent them from managing loss-related stress. Researchers (e.g., Bevvino \& Sharkin, 2004; Boss, 2002) have argued that attributing a positive meaning to the loss experience is essential to an individual's ability to cope effectively. In this way, the meaning that a family assigns to the loss directly influences family functioning. For this reason, perceptions and 
meanings among family members become critical in understanding and treating distressed families (Antonovsky \& Sourani, 1988; Boss, 2002).

This idea that an individual's ability to adjust in the face of a stressful experience is influenced by the meaning the experience has for them is not new. Research on this issue has drawn on perspectives from clinical psychology (Frankl, 1970), social psychology (Kelley, 1971), and sociology (Antonovsky, 1979). Boss (1977) adds to these ideas by arguing that boundary ambiguity - the ambiguity of not knowing who is in and who is out of the family — also influences the family's coping in the face of loss. Boss (1999) proposes that families must constantly evaluate who is in and who is out of the system, particularly during times of transition, including when children leave for school, obtain jobs, enter into romantic relationships, get married, have children, and begin to care for their parents.

Boss (1977) hypothesizes that situations involving loss lead to dysfunction only if they result in a high degree of boundary ambiguity, which may take two forms. In the first, the individual is physically absent, but psychologically present. The family is preoccupied with the absent member, preventing the process of grieving and restructuring due to uncertainty surrounding facts about the loss. In the second type, the individual is physically present, but psychologically absent. The member is physically there, but not emotionally available to the family system (Boss, 1988). Boss (2004a) notes that these two types of ambiguous loss often overlap.

Boss (1980) also demonstrates that some families resolve the stress of membership change much more quickly than others. Boundary ambiguity helps explain how and why some families are more resilient to loss than others (Boss, 2002). Boss (2002) defines resilience as the process of more than simply surviving the experience, but actually thriving in the face of loss. Boss (1980) theorizes that the greater the boundary ambiguity associated with losses throughout the family life 
cycle, the higher the levels of individual and family dysfunction. Thus, some of these losses may be reduced through relationships in the classroom.

\section{Strategies}

Research has shown that when teachers are able to create a positive relationship with individual students in their class, the student will see the school as a supportive space where he or she can academically and socially engage (Hamre \& Pianta, 2001). Such positive relationships are defined as having closeness, warmth, and positivity (Hamre \& Pianta, 2001). However, what happens when teachers have not learned to identify a specific population, such as military children?

To create caring teacher-student relationships and nurturing environments for military children, teachers and teacher educators should focus on the following strategies:

1. Learn how to identify numerous variables in the classroom. Helping teacher candidates learn to identify military children and their families should be incorporated into pedagogical practices. For example, on the first day of class, many teachers have students write about their families, interests, or experiences. These papers often highlight the student's individual motivation and needs. Thus, teachers could similarly find ways to identify military families through writing at the start of the semester.

2. Review individual needs. As with all students in the class, military children need to have their individual needs addressed. This can be done through assessing students at the start of the year. Determining if there are areas in which the student will need more support and/or other areas where the student is ahead of the class.

3. Differentiate for military children. After students have been identified and assessed, teachers can take time to infuse aspects of the curriculum and the classroom to support them. For example, Dr. Biden shared that when her son, Beau, was deployed her 
grandchildren's teacher posted a picture of Beau in the classroom, which comforted the children. Likewise, teachers can differentiate assignments to correspond with the child's needs, such as writing letters to his or her parent or posting pictures of the deployed family members on a wall in the classroom that highlights individual students' family members.

4. Collaborate with the family. While military families may have different home structures due to deployment or parents returning home, having a comforting school environment will be beneficial to the students and parents alike. For example, a teacher should make an effort to have parents visit the classroom. This can be done through parent reading days, luncheons, and career days. Moreover, teachers can create parental meetings in the students' neighborhood or military base. By organizing a meeting in the neighborhoods, the parents who are single due to deployment will be able to attend more easily.

5. Recognize the signs of stress that may accompany boundary ambiguity. Teachers should be taught to observe for changes in behavior patterns that may signal distress, such as mood swings or loss of interest in school and social activities. For instance, a child who has recently experienced ambiguous loss may refuse to complete assignments both in class and outside of the classroom. Teachers can help a child who previously loved to participate in sports or a club and suddenly stops showing up for practice or withdraws from friends by asking parents come to watch their sporting or other social events. It is of import for the teacher to recognize that this student's behavior is new and to try to find the source. Interestingly, the family and student may not correlate such behavior with ambiguous loss. Therefore, once warning signs are identified, then teachers can collaborate with others to identify appropriate resources for the child. 


\section{Resources}

Currently, there are additional resources for teachers to use with military students and families. These resources can aid in assisting students who are within the population that is often overlooked.

1. Sesame Workshop's "Talk, Listen, Connect" project for military families: A website created by Sesame Street for military families that offers videos, storybooks, and workbooks to help children deal with deployments, injuries from war, and the death of a loved one. http://tinyurl.com/cdjh3w5

2. Zero to Three's Military Families Projects: This website was created to support preschool children who live in military families who have a parent that is deployed. http://tinyurl.com/cj2y35c

3. Books For Military Children: This website offers dozens of book titles ranging from ages newborn through early adulthood, focused on children and families in the military. Children and adolescent books are categorized by age and appropriateness. http://www.booksformilitarychildren.info/index.html

4. "Helping children cope when a loved one is on military deployment" by Allen, M. \& Staley, L. (2007); published by National Association for the Education of Young Children $(N A E Y C)$. An accessible journal article to help teachers working with students from military families. This article includes a list of children and adolescent literature to use when working with students. Some of these titles include: Daddy, Will You Miss Me? by Wendy McCormick; Daddy, You're My Hero! by Michelle Ferguson-Cohen; The Magic Box: When Parents Can't Be There To Tuck You In; When Dad's at Sea, by Mindy Pelton; and A Year Without Dad, by Jodi Brunson. http://tinyurl.com/d532lcd 
5. Military Child Education Coalition website: This website offers a wide assortment of resources for families and teachers on working with children living in military families. http://www.militarychild.org

6. Resources for Children, Teachers, and Families Affected by Military Deployment, NAEYC, March 2008: A two-page list of resources for military families, including book lists. http://tinyurl.com/c4vva58

7. Facts for Families, "Families in the Military," American Association of Child and Adolescent Psychiatry: This website offers resources for all family members who may be raising children while their parents are deployed. http://tinyurl.com/cevqjfg:

\section{Conclusion}

Peeples (2016) recently challenged educators to become change agents. Similar to Dr.

Biden, Peeples encourages us, as teachers, to go first and become "fierce promoters" who create hope for children. The time has come to focus on the needs of military children within classrooms. These children will find hope in attending a nurturing classroom, where they share a caring relationship with their teachers. To build such relationships, teachers need to implement strategies such as those above and look more closely at behavior patterns that can be effective in identifying military children's individual needs, including ambiguous loss. 


\section{References}

Abell, C. S. (2004). Prepared statement: Quality of life. Paper presented at the meeting of the Senate Armed Services Personnel Subcommittee, Washington, DC.

Antonovsky, A. (1979). Health, stress and coping. San Francisco: Jossey-Bass.

Antonovsky, A., \& Sourani, T. (1988). Family sense of coherence and family adaptation. Journal of Marriage and the Family, 50, 79-92.

Bevvino, D. L., \& Sharkin, B. S. (2004). Divorce adjustment as a function of finding meaning and gender differences. Journal of Divorce and Remarriage, 39, 81-97.

Blaisure, K. R., Saathoff-Wells, T., Pereira, A., MacDermid Wadsworth, S. M., \& Dombro, A. L. (2012). Serving military families in the 21 st century. New York: Routledge.

Boss, P. (1977). A clarification of the concept of psychological father presence in families experiencing ambiguity of boundary. Journal of Marriage and the Family, 39, 141-151.

Boss, P. (1980). Normative family stress: Family boundary changes across the life span. Family Relations, 29, 445-450.

Boss, P. (1988). Family stress management. Newbury Park, CA: Sage.

Boss, P. (1992). Primacy of perception in family stress theory and measurement. Journal of Family Psychology 6(2), 113-119.

Boss, P. (1999). Ambiguous loss: Learning to live with unresolved grief. Cambridge, MA: Harvard University Press.

Boss, P. (2002). Family stress management: A contextual approach ( $\left.2^{\text {nd }} \mathrm{ed}.\right)$. Thousand Oaks, CA: Sage.

Boss, P. (2004a). Ambiguous loss research, theory, and practice: Reflections after 9/11. Journal of Marriage and Family, 66, 551-566.

Boss, P. (2004b). Ambiguous loss. In F. Walsh \& M. McGoldrick (Eds.) Living beyond loss: Death in the family ( $2^{\text {nd }}$ ed.). New York: W. W. Norton \& Company.

Boss, P., Pearce-McCall, D., \& Greenberg, J. (1987). Normative loss in mid-life families: Rural, urban, and gender differences. Family Relations, 36, 437-443.

Frankl, V. E. (1970). Will to meaning: Foundations of and application of logotherapy. New York: New America. 
Guidry, K., Simpson, C., Test, T. \& Bloomfield, C. (2013). Ambiguous loss and its effects on children: Implications and interventions for school counselors. Journal of School Counseling, 11(15).

Hamre, B. K., \& Pianta, R. C. (2001). Early teacher-child relationships and the trajectory of children's school outcomes through eighth grade. Child Development, 72(2), 625-638.

Holmes, A. K., Rauch, P. K., \& Cozza, S. J. (2013). When a parent is injured or killed in combat. Future of Children, 23(2), 143-162.

Hosek, J. \& MacDermid Wadsworth, S. (2013). Economic conditions of military families. Future of Children, 23(2), 41-59.

Kelley, H. H. (1971). Attribution in social interaction. Morristown, NJ: General Learning Press.

Peeples, S. (2016). Dare to go first. Educational Leadership, 73, 10-14.

U.S. Department of Defense. (2012). 2011 Demographics report: Profile of the military community. Published by the Office of the Deputy Under Secretary of Defense (Military Community and Family Policy), under contract with ICF International, Washington, DC. http://www.icfi.com/workforce. 